\title{
Geological and Geotechnical Parameters Controlling Wall Paints Detachment at Selected XXVI Dynasty Tombs, Bahariya Oasis, Egypt
}

\author{
Shehata A. A. ${ }^{1}$, G. M. E. Kamh ${ }^{2}$, C.T. Oguchi ${ }^{3}$ R. A. Rabea ${ }^{4}$, S. S. M. El-Sayed ${ }^{5}$ \\ 1- Prof. of Conservation, Dept. of Restoration and Conservation, Faculty of Archaeology, Fayum University, Egypt \\ 2- Prof. of Geoarchaeology, Geology Dept., Faculty of Science, Menoufiya University, Egypt \\ 3- Associated Prof., Geosphere Research Institute, Saitama University, Japan \\ 4- Restoration Authority, Ministry of Antiquities, Atfih, Egypt \\ 5- Restoration Dept., Ministry of Antiquitie, Egyptian Antiquities, Egypt
}

\begin{abstract}
Detection and semi-quantification of weathering processes acting on a given archaeological site is more than half way of stone's conservation to survive for longer decades or centuries revealing non-recovered part of nations' history. Bahariya Oasis in the heart of the Western Desert of Egypt has much recently discovered archaeological sites almost related to $26^{\text {th }}$ Dynasty i.e. 2650 YBP. It still requires detailed studies on it regarding several fields of research among those are: weathering processes and intensity on wall paints of these sites.

The main aims of the current study is to find out the impact of bedrock's iron oxide content on wall paints of the structures excavated through it, and to semi-quantify damage category at the two , Badi Eshtar and Bannantiu, tombs under investigation that are related to $26^{\text {th }}$ Dynasty at Bahariya Oasis. Detailed field survey including reporting and measuring weathering features' dimensions as well as air temperature and relative humidity inside and outside these sites in Winter and Summer Seasons have been conducted. Then, laboratory investigations including SEM, XRF, MIP and Ultrasonic waves have been applied on light and dark brown facies at these sites. The net result is moisture condensation inside these tombs particularly in summer as well as micro-pore size distribution, controlled by iron oxide concentration in this bedrock, with the aid of clay content resulted in rock's weathering ranging from Moderate to Very severe damage category at Badi Eshtar Tomb, and from Severe to Very Severe at Bannantiu Tomb.

Urgent controlling air temperature and relative humidity inside such excavations at Bahariya Oasis, and organized plan of paint's restoration are recommended for such unique rock art in the Western Desert of Egypt.
\end{abstract}

Keywords: Weathering of ancient wall paints, iron oxide content, field and laboratory studies, semi-quantification of damage category

\section{Introduction}

The archaeological sites are remains that reveal parts of nations' history that we have not lived yet. Weathering processes are among the very deleterious factors that partly or completely demolish such remains. They are acting either physically, chemically and/or biologically solely and/or in combination with different ranks of aggression based on the prevailing environmental conditions at a given area as well as rock's physical and geotechnical properties' limits (Elaine et al., 1992 and Salman et al., 2010). The damage category, especially for a given archaeological site, that can be defined using field and laboratory investigations (Kamh, 2007; Kamh and Azzam, 2008) is not only a result of stone's deterioration, starting from rock's surface grain's liberation up to detachment of mega rock parts via connected fractures or mechanical un-stability of the rock body, but also a factor of wall paints' damage that starts from degradation of original color intensity up to removal of this thin wall paints. It is unusual to find wall paints with its original color intensity, after few years in recent buildings or thousands of years for a given archaeological site, but almost experience fainting color's intensity and/or partial to complete demolishing of these paints.

Previous literatures in this field as well as actual field survey indicated that the ancient Egyptian wall paints, dated back even to the $4^{\text {th }}$ Dynasty i.e. up to 4560 YBP., are highly stable in color's intensity over thousands of years (Shin and Frank, 1993 and Vendrell et al., 1996). Other natural and/or induced processes may result in degradation and/or demolishing of wall paints at a given archaeological site e.g. condensation of air moisture within excavations and semiclosed structures particularly if noticeable difference in air's temperature is recorded from outside to inside this site (Mustoe, 1983; Gauri et al., 1986; Gauri, 1990; Elaine et al., 1992; Waltham, 1993; Salman et al., 2010; Rudrich et al., 2011). The moisture condensation inside a given excavation can be also a result of huge number of tourists or visitors entering such semi-closed site. Air pollutants and/or biological excretions at such painted parts have also been reported as destructive agents to such paints (Salman et al., 2010). Rock's physical and geo-technical properties' limits are among the parameters that define its susceptibility to weathering including paints on it. Recently generated active cracks, particularly the interconnected ones, severely affect on rock's body with its paints through detachment of rock masses with paints on it (GSEGWP, 1977; Robinson and Williams, 1994). Salt weathering is widely recorded as damaging process even for highly durable rocks at a wide range of environments (Flatt, 2002; Angeli et al., 2007; Cardell et al., 2008; Swe and Oguchi, 2009). It acts through one or more mechanism based on salt's type and the prevailing environmental conditions in particular air's temperature and relative humidity (Fitzner and Heinrichs, 2002; Flatt et al., 2007).

Keeping these backgrounds in mind, the present study aims to find out the main reason(s) behind wall paints' detachment (with its holding rock body) and/or obliteration, also to semi-quantify damage category from the archaeological point of view considering Badi-Eshtar and Bannantiu Tombs of XXVI Dynasty (2650 YBP) as case studies at Bahariya Oasis, Western Desert, Egypt. 


\section{Geological setting and History of the Study area}

Bahariya Oasis is, one of the ten depressions, setting in the heart of the Western Desert of Egypt at a distance of $365 \mathrm{~km}$ South-west of Giza Governorate. Its capital is Bawiti town, and it has several natural water springs, plants and vegetations. This oasis is oval shaped with maximum length axis $90 \mathrm{~km}$ running NE-SW direction, and maximum width 40km (Fig. 1). Its rock units are ranging in age from Upper Cretaceous to Oligocene (Said, 1990) and can be arranged from the oldest to the youngest as follows:

Bahariya Formation (Upper Cretaceous "Cenomanian age" 360m thick of alternative thin beds of fine to medium size glauconitic to ferruginous sand and silt, thin iron bands and glauconite can be traced).

Heiz Formation (Upper Cretaceous "Turonian-Campanian age" unconformably overlying Bahariya Formation with angular unconformity. It is vuggy hard dolomitic beds with thickness up to $30 \mathrm{~m}$ thick, it is acting as a cap rock for Bahariya Formation at some places of Bahariya Oasis).

Hefhuf Formation (Upper Cretaceous "Campanian-Maastrachtian age" hard mottled dolomitic thick bed of 43m thick).

Ain Giffara Formation (Upper Cretaceous "Maastrachtian age” Phosphatic Sandstone beds of 25m thick)

Radwan Formation (Oligocene Basalt of $25 \mathrm{~m}$ thick with columnar joints ended by pillow lava on it indicating marine volcanic origin, Unconformable lying on Bahariya Formation).

The historical remains, archaeological sites, at Bahariya Oasis have been recently discovered by chance on falling down one of the animals in a hole of sub-surface archaeological excavation. From that time, continuous and succeeding excavations and exploration of sub-surface structures as well as structures lying underneath sand-piles have been progressed. Bahariya Oasis has many and unique archaeological sites that almost related to $26^{\text {th }}$ Dynasty "2650 YBP" of the Egyptian history. Great Alexander Temple, El-Meftalla Temple, Bannantiu Tombs, the Valley of Golden Monuments are among the very precious detections at Bahariya Oasis.

Bahariya Oasis is a rich field for geological studies regarding its rock units and/or Iron Ore mine "El-Gedida Mine", but it is still virgin for geo-archaeological and restoration studies. The only recorded geo-archaeological study at Bahariya Oasis is that conducted for examining weathering processes acting on Great Alexander and Meftalla Temples as well as Ged Amun Euf Ankh Tombs (Horiya, 2012). It indicated that salt weathering as well as wind blown with sand is almost the main weathering processes at these sites. These sites still require detailed studies to quantify damage category and modes of conservation particularly for wall paints that are considered as the first victim to weathering processes. The wall paints at these sites, represent the main document revealing part of the Egyptian history at Bahariya Oasis, suffer demolishing to pronounced limits that ring a high alarm for defining and quantifying damage categories and examining the best modes of its preservation.

\section{Methodology}

To achieve the aims of the current study, two sites namely Bannantiu and Badi-Eshtar Tombs (Figs. 1 - 3) have been selected to conduct detailed field and laboratory investigations on them to semi-quantify damage category for the painted walls at the Main Court of these tombs as well as to examine the main reason(s) behind deterioration of these wall paints.

\section{1- $\quad$ Field Investigations}

Detailed field description and measuring dimensions of weathering forms and apparent stone's color at painted parts experiencing obliteration have been conducted at these sites preceding the detailed laboratory investigations. This is to group weathering forms and preliminary semi-quantify damage category at these sites from the archaeological point of view using Fitzner and Heinrichs (2002) classifications, for grouping weathering forms and defining its damage category respectively, listed as follows:

Group 1: Loss of stone material (L.S.); includes back weathering represented by cavernous weathering, obliteration of inscriptions and wall paints.

Group 2: Discoloration/ Deposits (D.D.); includes loose salt deposits e.g. salt efflorescence, pollutants as black crust, biological colonization.

Group 3: Detachment (D.T.); includes separation of small or large size part of rock body in the form of granular disintegration "rock meal", scaling, exfoliation.

Group 4: Fissures / Deformation (F.D.); includes all types of fissures i.e. single, map and/or multiple cracks, also describes cracks' aperture width, tilting angel from the vertical and crack's density "number of cracks/square meter" for a given wall side.

After grouping of weathering forms at the study area and its tabulation, the damage category can be defined using Fitzner and Heinrichs (2002) classification:

Damage Category 0: No visible damage can be noted

Damage Category 1: Faint damage can be noted

Damage Category 2: Slight damage can be noted

Damage Category 3: Moderate damage can be noted

Damage Category 4: Severe damage can be noted

Damage Category 5: Very severe damage can be noted 
But as this classification is not restricted with any limits or percentages for weathering forms, so, it has been modified in the current study to be more and widely applicable and precisely defines damage category regarding weathering forms listed in the four groups mentioned above. The modified classification of damage category can be presented as follows: Damage Category 0: No visible damage can be recorded regarding stone's surface and/or its inscriptions and paints.

Damage Category 1: Very slight damage can be recorded i.e. rock body presents weathering forms that are grouped into D.D., D.T. and/or L.S. on its inscriptions and/or paints to less than $5 \%$ of the rock body area.

Damage Category 2: Slight damage category can be recorded i.e. rock body presents weathering forms that are grouped into D.D., D.T., L.S. and/or F.D on its inscriptions and/or paints at 5 to $10 \%$ of the rock body area.

Damage Category 3: Moderate damage category can be recorded i.e. rock body presents weathering forms that are grouped into D.D., D.T., L.S. and/or F.D. on its inscriptions and/or paints at 10 to $25 \%$ of the rock body area.

Damage Category 4: Severe damage category can be recorded i.e. rock body presents weathering forms that are grouped into D.D., D.T., L.S. and/or F.D. on its inscriptions and/ or paints at 25 to $50 \%$ of the rock body area.

Damage Category 5: Very severe damage category can be recorded i.e. rock body presents weathering forms that are grouped into D.D., D.T., L.S. and/or F.D on its wall mass body and inscriptions only, as paints at D.C. 5 is almost totally demolished, at more than $50 \%$ of the rock body area.

On defining damage category for each part of the tombs under investigation regarding each weathering form, the overall damage category of each part considering all weathering forms can be defined using Damage Category including All Weathering forms' Scheme (DCAW) of Fitzner and Heinrichs (2002) that is only based on detailed measuring weathering forms' dimensions. This scheme reflects the degree of urgency and necessity of site's restoration if required. Air temperature and relative humidity over four field trips to these sites, two times in each of Summer (June and July 2012) and Winter (January and February, 2012) Seasons, have been conducted using thermometer and humidity meter with two sensors for simultaneous measurements inside and outside each site. This is to find out one of the expected reasons of moisture's condensation inside these tombs if measurements proves this, the data will be used in the explanation of wall paints' deterioration at these sites.

\section{2- Laboratory Investigations}

Small rock samples had been collected at the parts presenting wall paints' deterioration, then, they have been prepared to cover the required analyses. Those parts used for SEM have been coated with gold and examined at high magnification of SEM (S-2400). Electron Dispersive X-ray (EDX) has been mainly used to check the yellow and brown color content of the collected rock samples as well as to define clay mineral type if noted within rock's texture.

For the geotechnical investigations for the collected rock samples, ultrasonic waves have been used. The rock samples have been prepared for investigation by magneto-structive ultrasonic waves' tool to measure the velocity of these waves

"Cp" in two directions at right angel to each other for the collected samples at these tombs, to find out rock's isotropism. Rock's internal friction "Qc" has also been measured as it reflects rock's porosity and weathering grade (Montoto et al., 1981). Both of Cp and Qc have been measured for the collected rock samples following Kapranos et al (1981) equations listed as follows:

$[(\mathrm{Ao}+\mathrm{At}) /(\mathrm{Ao}-\mathrm{At})]=\mathrm{X}$

$(\pi \mathrm{n} / \mathrm{Qc})=\{\ln [2 /(1-\mathrm{X})]\} /(1+\mathrm{X})$

$\mathrm{Cp}=2 \mathrm{Lf} / \mathrm{n}$

Where $\mathbf{A}_{\mathbf{o}}$ and $\mathbf{A}_{\mathbf{t}}$ are initial and steady magnitude of the ultrasonic waves; $\mathbf{n}$ is the mode number at which we get the best Echo-form for the waves; $\mathbf{Q c}$ is material's internal friction; $\mathbf{C p}$ is the velocity of the ultrasonic waves; $\mathbf{L}$ is the sample's length "cm"; $\mathbf{f}$ is the frequency of the waves.

Rock and pore's properties have been considered in the current study as they had been reported to play an effective role in rock's deterioration and controls rock's susceptibility to weathering (Cardell et al., 2008). It has been conducted for the collected rock samples using MIP-5900 at conditions of low and high mercury pressure (31.04 psia to 33000 psia respectively) to get a measure for all samples' macro- and micro-pores.

The rock's natural moisture content has been measured for the collected rock samples, that had been stored in highly sealed plastic bags to keep its natural moisture content until measurements directly in the laboratory, following the method and equation of Robinson (1974) listed as follows:

Moisture content $=\left[\left(\mathrm{W}_{1}-\mathrm{W}_{2}\right) / \mathrm{W} 1\right] * 100$, where $\mathrm{W}_{1}$ is sample's weight at field conditions, $\mathrm{W}_{2}$ is oven totally dried sample at $105^{\circ} \mathrm{C}$ for $24 \mathrm{~h}$.

\section{Results}

The following is a list of field and laboratory investigations conducted for the sites under investigation.

\section{I- $\quad$ Field Investigations}

Field investigations are recommended to be conducted as it is less expensive, quick and non-destructive technique for semi-quantitative definition of damage category for a given site (Fitzner and Heinrichs, 2002; Kamh, 2007; and Kamh and Azzam, 2008). The local environmental conditions and detailed description of weathering features are the pre-requests for explanation of weathering mechanism and semi-quantification of damage category at a given site respectively.

The local climatic conditions at the two tombs under investigation represented by temperature and relative humidity inside and outside these tombs had been measured two times in each of Summer and Winter Seasons (Table, 1). Pronounced temperature difference as well as relative humidity from outside to inside these tombs has been recorded particularly in Summer Season. The relative humidity is increased from outside to inside these tombs during Summer (Table, 1). 
Table 1: Local climate at the tombs under investigation

\begin{tabular}{|c|c|c|c|c|c|c|c|c|}
\hline \multirow{2}{*}{. } & \multirow{2}{*}{ 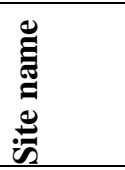 } & \multirow[b]{2}{*}{ है } & \multirow{2}{*}{ 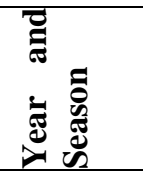 } & \multirow{2}{*}{$\stackrel{\overrightarrow{0}}{\underline{0}}$} & \multicolumn{2}{|c|}{$\begin{array}{l}\text { Local Climate inside } \\
\text { tombs }\end{array}$} & \multicolumn{2}{|c|}{$\begin{array}{l}\text { Local climate outside } \\
\text { tombs }\end{array}$} \\
\hline & & & & & $\begin{array}{l}\text { Average } \\
\text { Temp. C }\end{array}$ & $\begin{array}{l}\text { Average } \\
\text { Rh \% }\end{array}$ & $\begin{array}{l}\text { Average } \\
\text { Temp. C }\end{array}$ & $\begin{array}{l}\text { Average } \\
\text { Rh \% }\end{array}$ \\
\hline \multirow{8}{*}{ 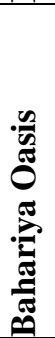 } & \multirow{4}{*}{ : } & \multirow{8}{*}{ 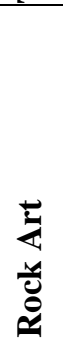 } & \multirow{2}{*}{$\begin{array}{l}\text { Winter } \\
2012\end{array}$} & Jan. & 15 & 40 & 12 & 55 \\
\hline & & & & Feb. & 17 & 39 & 14 & 52 \\
\hline & & & \multirow{2}{*}{$\begin{array}{l}\text { Summer } \\
2012\end{array}$} & June & 17 & 66 & 40 & 30 \\
\hline & & & & July & 18 & 69 & 42 & 29 \\
\hline & \multirow{4}{*}{ 䓌 } & & \multirow{2}{*}{$\begin{array}{l}\text { Winter } \\
2012\end{array}$} & Jan. & 19 & 39 & 18 & 50 \\
\hline & & & & Feb. & 20 & 40 & 17 & 48 \\
\hline & & & \multirow{2}{*}{$\begin{array}{l}\text { Summer } \\
2012\end{array}$} & June & 18 & 67 & 40 & 31 \\
\hline & & & & July & 19 & 66 & 41 & 30 \\
\hline
\end{tabular}

The sites under investigation suffer weathering including wall paints and its holding bedrock (Fig. 4). Semiquantification of damage category regarding each weathering form (considering the main court) at each site has been defined using the modified scale of Fitzner and Heinrichs (2002) and weathering forms' dimensions listed in table (2).

The overall damage category for the painted walls in the Main Court of each site has been defined considering all weathering forms together using DCAW Scheme (Figs. 5 and 6). It has been indicated that the damage category at Badi Eshtar Tomb ranges from Moderate (at parts with light brown facies "at samples numbers 3 and 4", Fig. 5) to Very severe damage category (at parts with dark brown facies "at samples numbers 1 and 2", Fig. 5). On the other hand, at Bannantiu Tomb, it ranges from Severe (at parts with light color facies "at samples numbers 7 and 8", Fig. 6) to Very severe damage category (at parts with dark brown facies "at samples numbers 5 and 6", Fig. 6). The main reason behind this difference in DC at both tombs will be explained with the detailed laboratory analysis, in the discussion section, conducted for rock samples collected at these tombs.

\section{II- Laboratory Investigations}

Detailed laboratory investigations have been conducted on the rock samples collected at light and dark brown color parts representing the bedrock through which these sites had been excavated. This is to examine rock's weathering on micro-scale, clay content and relative difference in elemental composition of these facies that might throw light on the main reason(s) behind deterioration of this bedrock with its wall paints particularly at the dark facies compared with the light color one. The bedrock's geotechnical properties and natural moisture content for the two types of facies have also been measured.

\section{II-1- Micro-petrographic investigation}

Two rock samples at each site (one at each of light and dark brown color facies) have been scanned using SEM (S-2400). Great similarity and matching have been noted in texture and mineralogy at both tombs as they had been excavated in the Bahariya Formation and nearly at the same sector of this rock unit. The facies can be identified as fine to very fine sandstone and siltstone with kaolinite and smectite cement either at the light and/or dark brown parts of this bedrock (Figs. 7 and 8). Iron oxide spheres are almost noted in the dark brown samples rather than the light color samples at these sites (Fig. 9). K-feldspar and kaolinite presents deformation and/or loosing cohesion among its lattice and flakes (Figs. 7 and 8).

\section{II-2- Elemental analysis}

It has been recommended to be conducted for numerical elemental quantification and identification to specifically differentiate between the light and dark brown facies that hold paints suffering demolishing, the results are listed in table (3). It is clearly noted that $\mathrm{SiO}_{2}$ represents the main component of these facies as it is siliceous rock in sand and/or silt size. Iron oxide represents a considerable percentage of rock's elemental composition with higher percentages for dark brown facies than light color facies (Table, 3). Other elemental components e.g. Oxides of Al, K are components of clay minerals.

\section{II-3- Geotechnical properties and Natural moisture content}

The ultrasonic waves has been widely used as a non-destructive technique to reflect the geotechnical properties of a given material including rocks i.e. semi-quantitatively defines its porosity level that is in an inverse proportional relation with the velocity of these waves "Cp" on one hand, and in a direct proportional relation with rock's internal friction "Qc" on the other hand (Calleja et al., 2000). In the current study, the light as well as dark brown facies have the same mineralogical composition with exception of iron oxide concentration in both (Table, 3), this might affect on rock's geotechnical limits, consequently, this technique has been applied for both facies using the collected rock samples to find out this difference if recorded. The sample's preparation and parameters computation have been conducted following Kapranos et al (1981) method and equations, the data are listed in table (4). A noticeable difference in rock's geotechnical properties limits can be noted from light to dark brown color parts at this bedrock particularly at Bannantiu Tomb; also the bedrock is an-isotropic particularly for the dark brown facies at both tombs and the light brown facies at Bannatiu Tomb 
(Table, 4) compared with light color facies at Badi Eshtar Tomb. This an-iso-tropism might be a result of iron oxide concentration (Table, 3) within these facies (Fig. 9) particularly along its lamina

Table 2: Weathering features and damage category at the dark and light brown facies for the tombs under investigation

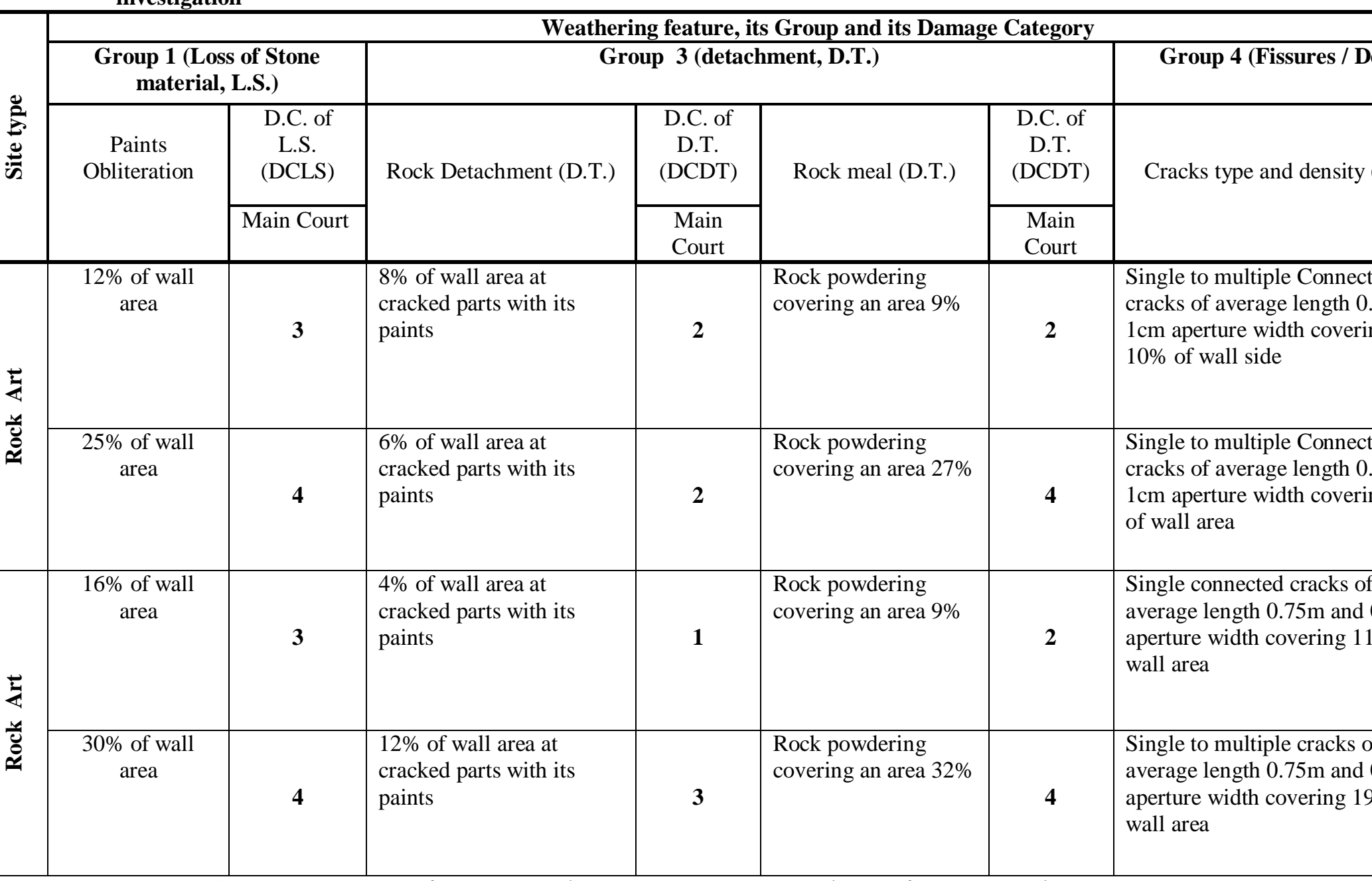

N.B. L.S. is Group "1" Loss of Stone material; D.T. is Group "3” Detachment of stone material; F.D. is Group "4" Fissures/Deformation

Table 3: X-ray Flourescence analysis for eight rock samples collected at the tombs under investigation

\begin{tabular}{|c|c|c|c|c|c|c|c|c|c|c|c|}
\hline \multirow[t]{2}{*}{ Location } & \multirow[t]{2}{*}{ Site name } & \multirow[t]{2}{*}{ Type } & \multirow{2}{*}{$\begin{array}{c}\text { Sample } \\
\text { No. }\end{array}$} & \multirow{2}{*}{$\begin{array}{c}\text { Sample } \\
\text { color }\end{array}$} & \multicolumn{7}{|c|}{ Elemental Oxide \% } \\
\hline & & & & & $\mathrm{CaO}$ & $\mathrm{SiO} 2$ & $\mathrm{FeO}$ & $\mathrm{K} 2 \mathrm{O}$ & $\mathrm{Al} 2 \mathrm{O} 3$ & $\mathrm{SO} 2$ & $\mathrm{MnO}$ \\
\hline \multirow{8}{*}{ 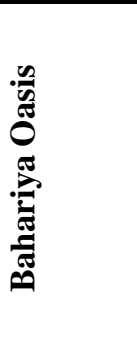 } & \multirow{4}{*}{$\begin{array}{l}\text { Badi } \\
\text { Eshtar } \\
\text { Tomb }\end{array}$} & \multirow{8}{*}{ 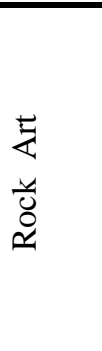 } & 1 & \multirow{2}{*}{$\begin{array}{c}\text { Dark } \\
\text { Brown }\end{array}$} & 0.32 & 76.71 & 13.02 & 2.14 & 1.79 & 0.69 & 5.33 \\
\hline & & & 2 & & 0.91 & 73.02 & 16.34 & 1.99 & 2.56 & 1.06 & 4.12 \\
\hline & & & 3 & \multirow{2}{*}{$\begin{array}{c}\text { Light } \\
\text { Brown }\end{array}$} & 0.06 & 82.07 & 1.06 & 3.86 & 4.02 & 1.98 & 5.95 \\
\hline & & & 4 & & 0.99 & 85.22 & 1.11 & 2.86 & 3.23 & 1.58 & 4.01 \\
\hline & \multirow{4}{*}{$\begin{array}{c}\text { Bannantiu } \\
\text { Tomb }\end{array}$} & & $\overline{5}$ & \multirow{2}{*}{$\begin{array}{c}\text { Dark } \\
\text { Brown }\end{array}$} & 0.73 & 71.75 & 15.02 & 2.55 & 3.04 & 1.43 & 5.48 \\
\hline & & & 6 & & 1.03 & 70.34 & 16.23 & 1.95 & 2.63 & 0.88 & 6.94 \\
\hline & & & 7 & \multirow{2}{*}{$\begin{array}{l}\text { Light } \\
\text { Brown }\end{array}$} & 0.54 & 83.27 & 6.12 & 1.67 & 3.02 & 0.77 & 9.68 \\
\hline & & & 8 & & 0.87 & 82.97 & 5.81 & 1.43 & 2.89 & 1.07 & 8.71 \\
\hline
\end{tabular}


Table 4: Geotechnical properties and Natural moisture content measured for eight rock samples collected at the tombs under investigation

\begin{tabular}{|c|c|c|c|c|c|c|c|c|c|c|}
\hline \multirow{2}{*}{ 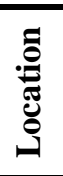 } & \multirow{2}{*}{ 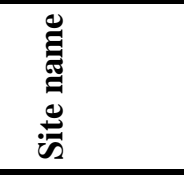 } & \multirow{2}{*}{$\sum_{0}^{\circ}$} & \multirow{2}{*}{ 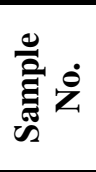 } & \multirow{2}{*}{ 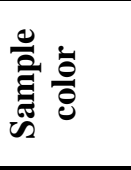 } & \multicolumn{4}{|c|}{ Geotechnical Properties } & \multicolumn{2}{|c|}{$\begin{array}{c}\text { Rock's Natural } \\
\text { Moisture Content \% }\end{array}$} \\
\hline & & & & & $\begin{array}{c}\mathrm{Cp} 1 \\
\text { "Km/Sec" }\end{array}$ & $\begin{array}{c}\mathrm{Cp} 2 \\
\text { "km/sec" }\end{array}$ & $\begin{array}{l}\text { Isotropism } \\
\text { "Cp1/Cp2" }\end{array}$ & Qc & Winter & Summer \\
\hline \multirow{8}{*}{ 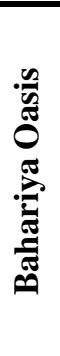 } & \multirow{4}{*}{$\begin{array}{l}\text { Badi Eshtar } \\
\text { Tomb }\end{array}$} & \multirow{8}{*}{ 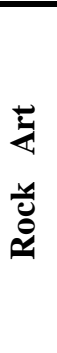 } & 1 & \multirow{2}{*}{$\begin{array}{c}\text { Dark } \\
\text { Brown }\end{array}$} & 2.26 & 2.01 & 1.12 & 7.20 & 10.40 & 14.30 \\
\hline & & & 2 & & 2.21 & 2.00 & 1.11 & 6.80 & 11.20 & 13.80 \\
\hline & & & 3 & \multirow{2}{*}{$\begin{array}{l}\text { Light } \\
\text { Brown }\end{array}$} & 1.95 & 1.89 & 1.03 & 9.12 & 7.92 & 9.12 \\
\hline & & & 4 & & 1.91 & 1.88 & 1.02 & 9.07 & 7.88 & 9.64 \\
\hline & \multirow{4}{*}{$\begin{array}{l}\text { Bannantiu } \\
\text { Tomb }\end{array}$} & & 5 & \multirow{2}{*}{$\begin{array}{c}\text { Dark } \\
\text { Brown }\end{array}$} & 2.22 & 2.03 & 1.09 & 6.91 & 11.60 & 14.90 \\
\hline & & & 6 & & 2.24 & 2.02 & 1.11 & 6.71 & 10.90 & 14.80 \\
\hline & & & 7 & \multirow{2}{*}{$\begin{array}{l}\text { Light } \\
\text { Brown }\end{array}$} & 2.02 & 1.85 & 1.09 & 8.62 & 8.30 & 9.98 \\
\hline & & & 8 & & 2.05 & 1.87 & 1.10 & 8.37 & 8.20 & 10.57 \\
\hline
\end{tabular}

N.B. Cp1 and Cp2 are velocity of the ultrasonic waves measured parallel to and at right angel to lamination respectively; Qc is rock's internal friction, and Ed is rock's elastic modulus

For detailed investigation and differentiation in rock and pore's properties at the two facies under investigation, MIP has been used, the results are listed in table (5) and the pore size distribution for the two facies at both tombs is graphically presented in figures (10 and 11). Lower values of total porosity, mean pore diameter and total pore area can be noted for dark facies compared with light color facies and vise versa for skeletal density (Table, 5). Pronounced matching in pore properties can be recognized in pore size (radius) distribution as graphically presented from MIP data particularly for dark color facies (Figs. 10 and 11). The Incremental Pore Volume "IPV" data indicates slightly lower values for dark facies compared with light color facies (Table, 6), this might be a result of filling rock pores partially with iron oxide spheres. The micro-porosity has been analyzed to find out the critical pore size or pore size's range at which salt weathering and/or rock's water sorption reaches to maximum limit based on previous literatures (Angeli et al., 2007; Swe and Oguchi, 2009), the percentage of each pore radii range in the examined samples is listed in table (6). This will clarify the reason(s) behind higher damage at dark facies with its wall paints compared with light color facies. On measuring natural moisture content in the two facies during Summer and Winter seasons, it can be noted higher moisture content (\%) recorded for samples collected in Summer Season compared with same facies but collected in Winter Season on one hand; and for dark brown facies compared with light color one at the same season on the other hand (Table, 4).

Table 5: Rock pore properties for the samples collected at the sites under investigation using MIP-5900

\begin{tabular}{|c|c|c|c|c|c|c|c|c|}
\hline \multirow[b]{2}{*}{ Location } & \multirow[b]{2}{*}{ Site name } & \multirow[b]{2}{*}{$\begin{array}{l}\text { Site } \\
\text { Type }\end{array}$} & \multirow[b]{2}{*}{$\begin{array}{c}\text { Sample } \\
\text { No. }\end{array}$} & \multirow[b]{2}{*}{$\begin{array}{c}\text { Sample } \\
\text { color }\end{array}$} & \multicolumn{4}{|c|}{ Rock and Pore Properties } \\
\hline & & & & & $\begin{array}{l}\text { TPA } \\
\text { " } \mathrm{m}^{2} / \mathrm{g} "\end{array}$ & $\begin{array}{l}\text { MPD (area) } \\
\text { "in micron" }\end{array}$ & $\begin{array}{l}\text { Skeletal density } \\
\text { "g/mL" }\end{array}$ & $\begin{array}{c}\text { Total porosity } \\
(\%)\end{array}$ \\
\hline \multirow{8}{*}{ 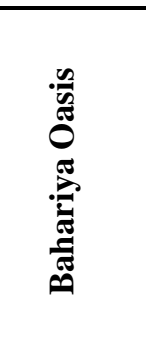 } & \multirow{4}{*}{$\begin{array}{l}\text { Badi } \\
\text { Eshtar } \\
\text { Tomb }\end{array}$} & \multirow{8}{*}{ 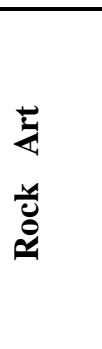 } & 1 & \multirow{2}{*}{$\begin{array}{c}\text { Dark } \\
\text { Brown } \\
\end{array}$} & 0.032 & 0.0399 & 2.450 & 18.004 \\
\hline & & & 2 & & 0.031 & 0.0376 & 2.420 & 19.213 \\
\hline & & & 3 & \multirow{2}{*}{$\begin{array}{l}\text { Light } \\
\text { Brown }\end{array}$} & 2.636 & 2.1975 & 2.274 & 25.196 \\
\hline & & & 4 & & 2.629 & 2.1971 & 2.199 & 25.321 \\
\hline & \multirow{4}{*}{$\begin{array}{c}\text { Bannantiu } \\
\text { Tomb }\end{array}$} & & 5 & \multirow{2}{*}{$\begin{array}{c}\text { Dark } \\
\text { Brown }\end{array}$} & 0.033 & 0.0399 & 2.540 & 18.373 \\
\hline & & & 6 & & 0.321 & 0.0395 & 2.440 & 19.342 \\
\hline & & & 7 & \multirow{2}{*}{$\begin{array}{c}\text { Light } \\
\text { Brown }\end{array}$} & 1.342 & 0.1874 & 2.355 & 23.520 \\
\hline & & & 8 & & 1.289 & 0.1906 & 2.328 & 22.970 \\
\hline
\end{tabular}

N.B. TPA is Total Pore Area; MPD is Mean Pore Diameter;

\section{Discussion}

Weathering of a given material is a matter of physical, chemical and/or biological disintegration and/or decomposition of its components. The product is either similar to the original mass but only fragmented probably from boulder to powder size i.e. physical damage, or partly to totally different in composition from the main rock i.e. chemical alteration. The severity of weathering particularly for a given archaeological site is not only a matter of debris volume detached from the main rock mass but also defined by the area and/or mass of the rock mass affected by this weathering particularly those parts holding inscriptions and/or paints that reveal part of ancient history for a given nation (Alison and Heritage, 2007 and Zehnder, 2007). Definition of weathering processes, mechanism(s) and semi-quantification or quantification (if possible) of damage category, all are of value for urgent decisions regarding conservation of a given site. Holding these points into mind, the current study has been conducted on two out of many excavations (rock art) at Bahariya Oasis that still virgin in the field of archaeological excavations and receives less attention for such sort of studies. At the study area, a noticeable difference in temperature from out-door to in-door of these tombs has been recorded particularly in Summer time (Table, 1), this has led to moisture condensation into these tombs particularly in Summer 
season where the full situation is reversed regarding relative humidity in Winter season (Table, 1). Based on the modified scale of Fitzner and Heinrichs (2002), the damage category regarding each weathering form at the dark and light color facies for the main court of each tomb has been specified (Table, 2). Then, semi-quantification of overall damage category considering all weathering features has been defined using "DCAW" Scheme of Fitzner and Heinrichs (2002) and plotting D.C. of each group (Table, 2) on this scheme (Figs. 5 and 6). Noticeable difference in overall damage category can be noted from dark brown facies to light brown one in the same tomb e.g. it is moderate and very severe for the light and dark facies at Badi Eshtar Tomb respectively, and severe to very severe for the light and dark facies at Bannantiu Tomb (Figs. 5 and 6) respectively. Binary relationship has been drawn between overall damage category and FeO $\%$ for the samples representing light and dark brown facies (Fig. 12). Direct proportional relation has been noted with correlation coefficient $\mathrm{R}^{2}=0.5086$, it can be considered as pronounced correlation coefficient but the reason behind its relatively low value is that $\mathrm{FeO} \%$ in the four samples representing dark facies at the two tombs is nearly the same (Table 3). The net result of this binary relation is that $\mathrm{FeO} \%$ is an effective factor in rock's susceptibility to weathering. But now, the questions have been raised, how is $\mathrm{FeO} \%$ content controls rock's susceptibility to weathering?, and is $\mathrm{FeO} \%$ a deleterious factor on rock's components?.

To answer these two questions, the rock's pore size distribution as well as its natural moisture content measured for eight rock samples representing the facies under investigation (Tables 6 and 4 respectively) in combination with rock's FeO\% and pore properties (Tables 3 and 5 respectively) indicate the following two points: (1) as iron oxide percentage increases, the pore diameter, pore area and incremental pore volume as well as rock's iso-tropism are decreased, consequently, rock's total porosity is reduced and its weathering susceptibility is increased if the rock has high percentage of micro-pores with critical pore radii, (2) at critical pore radii value or range that can be defined in this case study to be ranging from 0.1 to 1.0 micron, the rock's sorption for moisture or water is noticeably increased and this is clear in table (4) for the dark brown facies, at both tombs, that has higher percentage of pore radii ranging from 0.1 to 1.0 micron than light brown facies particularly at Badi Eshtar Tomb (Table 6, Fig. 11). At the same time, light color facies at Bannantiu Tomb has relatively higher FeO\% than that at Badi Eshatr Tomb (Table, 3), consequently, the pore size distribution is limited to less than 1.0 micron for the former and so, the wall paints at this facies suffers severe DC (Fig. 6). The pore size distribution for light brown facies at Bannantiu Tomb enables more sorption for air moisture compared with that of Badi Eshtar Tomb (Table, 4), consequently, higher DC is recorded for the former than that of the later (Figs. 6 and 5 respectively). Correlating $\mathrm{FeO} \%$ at the facies under investigation with each of natural moisture content (Table 4), rock's iso-tropism (Table, 4), rock and pore properties as well as pore size distribution (Tables, 5 and 6 respectively) and the overall DC (Figs. 5 and 6), it can be then confirmed with high confidence that $\mathrm{FeO} \%$ content controls rock's susceptibility to weathering (Fig. 12) by limitation of pore radii to critical pore volume that increases rock's sorption capacity. This high sorption capacity in combination with rock's clay (particularly smectite) content resulted in weakening rock's components cohesion force i.e. it is altered to friable or non coherent material and probably create and/or activate cracks on both micro and mega-scale that may result in detachment of small or big rock masses from the main rock body. It must be kept in mind that the direct proportional relation between $\mathrm{FeO} \%$ and rock's $\mathrm{DC}$ is not absolute where if FeO\% is increased above certain limit, then the rock may have high percentage of micro or nano-pores that are not effective in sorption of water molecules and/or salt solutions (Angeli et al, 2007; Benavente et al., 2007).

The probability of salt weathering to be one of the factors responsible for rock's deterioration at the study area is negligible where rock's $\mathrm{CaO} \%$ as well as $\mathrm{SO}_{2} \%$ (for creating sulfate salt) content is very low (Table 3). But in case of reaching salt(s) with salt solution to such bedrock particularly the dark color facies, it is expected to be very deleterious as this pore radii is critical for severe salt crystal growth by crystallization and /or hydration (Flatt, 2002; Cardell et al., 2008; Swe and Oguchi, 2009).

The wider range of pore radii at light brown facies at Badi Eshtar Tomb $(\leq 2.5$ micron, Table, 6$)$ associated with less $\mathrm{FeO} \%$ content (i.e. became widely distributed around the critical pore radii "1.0 to 0.1 micron") compared with that range of light brown facies at Bannantiu Tomb with noticeably high FeO\% content (i.e. became closely distributed around the critical pore radii, Table 6) resulted in Moderate Overall DC for the former compared with the Severe Overall DC for the later. Conclusively, the $\mathrm{FeO} \%$ even in the light color facies resulted in noticeable difference in rock's pore radii, consequently, the rock's sorption capacity differed (Table, 4) and so, the overall DC is noticeably varies (Figs. 5 and 6 ). Although the equality in overall DC for the dark facies at the two tombs (DC=5, Figs. 5 and 6), but this DC slightly differs from each other where it is relatively with higher rank at Bannantiu Tomb compared with Badi Eshtar Tomb, the reason behind that is the damage category Group 3 (DCDT) where the wall area (\%) affected by detachment at the former tomb is more than that at the later (Table, 2).

\section{Conclusion}

The facies under investigation are so similar in mineralogy and elemental composition with exception of iron oxide content that enable its differentiation into two sub-facies. The geotechnical properties' limits and pore size distribution, at the two tombs, are highly matching together particularly for the dark brown facies. The dark facies are expected to be with better geotechnical properties' limits than light color ones, but the pore size distribution that ranges (with higher percentages in the dark facies than light color one) from 0.1 micron to 1.0 micron enables moisture capturing in the pores of the dark facies than light color one. The clay (smectite and kaolinite) content particularly in the dark facies combined with moisture content presents more damage (rock meal and activation of fractures) for it rather than for light color facies. The end result is more demolishing of wall paints at dark facies than light color one. Conclusively, iron 


\section{International Journal of Modern Engineering Research (IJMER) \\ www.ijmer.com \\ Vol.2, Issue.6, Nov-Dec. 2012 pp-4166-4179 \\ ISSN: 2249-6645}

oxide content at Bahariya facies has a pronounced impact on rock's pore size distribution that is ended by higher damage category for dark facies with its wall paints than at light color (less in iron oxide content) one.

Table 6: Pore size distribution and Incremental Pore Volume for the collected rock samples

\begin{tabular}{|c|c|c|c|c|c|c|c|c|c|c|c|c|}
\hline \multirow[t]{2}{*}{$\begin{array}{l}\text { Locatio } \\
\text { n }\end{array}$} & \multirow[t]{2}{*}{$\begin{array}{c}\text { Site } \\
\text { name }\end{array}$} & \multirow{2}{*}{$\begin{array}{c}\text { Site } \\
\text { Typ } \\
\text { e }\end{array}$} & \multirow[t]{2}{*}{$\begin{array}{l}\text { Sampl } \\
\text { e No. }\end{array}$} & \multirow[t]{2}{*}{$\begin{array}{l}\text { Sampl } \\
\text { e color }\end{array}$} & \multicolumn{8}{|c|}{$\begin{array}{l}\text { Percentage of Pore Size Distribution and Incremental Pore Volume } \\
\qquad(\mathrm{mL} / \mathrm{g})\end{array}$} \\
\hline & & & & & $\begin{array}{c}<0.05 \\
\mu \mathrm{m}\end{array}$ & $\begin{array}{c}0.05- \\
0.1 \\
\mu \mathrm{m} \\
\end{array}$ & $\begin{array}{c}0.1- \\
0.5 \\
\mu \mathrm{m}\end{array}$ & $\begin{array}{c}0.5- \\
1.0 \\
\mu \mathrm{m}\end{array}$ & $\begin{array}{c}1.0- \\
2.5 \\
\mu \mathrm{m}\end{array}$ & $\begin{array}{c}2.5- \\
5.0 \\
\mu \mathrm{m}\end{array}$ & $\begin{array}{l}\mathbf{5 . 0} \\
\mu \mathrm{m}\end{array}$ & $\begin{array}{c}\text { IPV } \\
\text { " } \mathrm{mL} / \mathrm{g} \\
"\end{array}$ \\
\hline \multirow{8}{*}{ 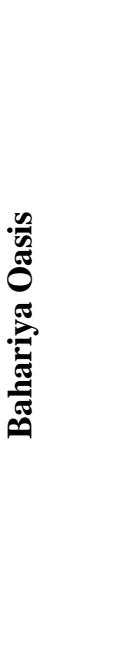 } & \multirow{4}{*}{$\begin{array}{l}\text { Badi } \\
\text { Eshtar } \\
\text { Tomb }\end{array}$} & \multirow{8}{*}{ 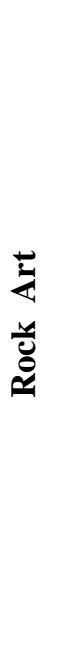 } & 1 & \multirow[t]{2}{*}{$\begin{array}{c}\text { Dark } \\
\text { Brown }\end{array}$} & 0.000 & $\begin{array}{c}4.800 \\
0\end{array}$ & $\begin{array}{c}33.92 \\
0\end{array}$ & $\begin{array}{c}48.54 \\
0\end{array}$ & 6.200 & $\begin{array}{c}1.36 \\
0\end{array}$ & $\begin{array}{c}6.61 \\
7\end{array}$ & 0.1160 \\
\hline & & & 2 & & 0.000 & $\begin{array}{c}4.690 \\
0\end{array}$ & $\begin{array}{c}33.76 \\
0\end{array}$ & $\begin{array}{c}48.93 \\
0\end{array}$ & 6.220 & $\begin{array}{c}1.03 \\
6\end{array}$ & $\begin{array}{c}6.49 \\
4\end{array}$ & 0.1166 \\
\hline & & & 3 & \multirow[t]{2}{*}{$\begin{array}{l}\text { Light } \\
\text { Brown }\end{array}$} & $\begin{array}{c}12.16 \\
0\end{array}$ & $\begin{array}{c}8.610 \\
0\end{array}$ & $\begin{array}{c}29.36 \\
0\end{array}$ & $\begin{array}{c}23.92 \\
0\end{array}$ & $\begin{array}{c}15.62 \\
0\end{array}$ & $\begin{array}{c}4.06 \\
0\end{array}$ & $\begin{array}{c}6.28 \\
0\end{array}$ & 0.1230 \\
\hline & & & 4 & & $\begin{array}{c}10.88 \\
0\end{array}$ & 9.900 & $\begin{array}{c}29.45 \\
0\end{array}$ & $\begin{array}{c}23.99 \\
0\end{array}$ & $\begin{array}{c}16.56 \\
1\end{array}$ & $\begin{array}{c}3.92 \\
0\end{array}$ & $\begin{array}{c}5.30 \\
5\end{array}$ & 0.1226 \\
\hline & \multirow[t]{4}{*}{$\begin{array}{l}\text { Bannanti } \\
\text { u Tomb }\end{array}$} & & 5 & \multirow[t]{2}{*}{$\begin{array}{l}\text { Dark } \\
\text { Brown }\end{array}$} & 0.000 & 4.800 & $\begin{array}{c}33.85 \\
0\end{array}$ & $\begin{array}{c}49.61 \\
0\end{array}$ & 5.215 & $\begin{array}{c}1.37 \\
0\end{array}$ & $\begin{array}{c}6.62 \\
4\end{array}$ & 0.1161 \\
\hline & & & 6 & & 0.000 & $\begin{array}{c}4.610 \\
0\end{array}$ & $\begin{array}{c}33.26 \\
7\end{array}$ & $\begin{array}{c}49.73 \\
0\end{array}$ & 6.090 & $\begin{array}{c}1.34 \\
0\end{array}$ & $\begin{array}{c}6.38 \\
0\end{array}$ & 0.1187 \\
\hline & & & 7 & \multirow[t]{2}{*}{$\begin{array}{l}\text { Light } \\
\text { Brown }\end{array}$} & $\begin{array}{c}18.04 \\
0\end{array}$ & $\begin{array}{c}28.72 \\
0\end{array}$ & $\begin{array}{c}22.49 \\
0\end{array}$ & $\begin{array}{c}13.03 \\
0\end{array}$ & 4.521 & $\begin{array}{c}3.92 \\
0\end{array}$ & $\begin{array}{c}9.26 \\
0\end{array}$ & 0.1224 \\
\hline & & & 8 & & $\begin{array}{c}26.03 \\
0\end{array}$ & $\begin{array}{c}25.72 \\
0\end{array}$ & $\begin{array}{c}18.53 \\
0\end{array}$ & $\begin{array}{c}13.02 \\
0\end{array}$ & 3.510 & $\begin{array}{c}3.92 \\
0\end{array}$ & $\begin{array}{c}9.28 \\
0\end{array}$ & 0.1225 \\
\hline
\end{tabular}

N.B. IPV is Incremental Pore Volume

\section{Acknowledgement}

The authors are deeply grateful to SU, Japan for conducting MIP analysis as well as SEM required for this research. Also, they are appreciating the comments and language reading and corrections by Dr. Heather Allison, MRI, UK.

\section{References}

1. Alison, S. and A. Heritage, 2007: Evaluating the influence of mixture composition on the Keinetics of salt damage in wall paintings using time Laps Video Imaging with the direct data annotation. Environmental Geology, V. 52, P. 303 -315 .

2. Angeli, M.; J. P. Bigas; D. Benavente; R. Hebert and C. David, 2007: Salt crystallization in pores: quantification and estimation of damage. Environmental Geology, V. 52, P. $205-213$.

3. Benavente, D.; N. Cueto; J. Martinez; M. A. Cura and J. C. Canaveras, 2007: The influence of petrophysical properties on the salt weathering of porous building rocks. Environmental Geology, V. 52, P. $215-224$

4. Calleja, L.; M. Montoto; B. Perez and B. M. Villar, 2000: An Ultrasonic method to analyze the progress of weathering during cyclic salt crystallization tests. Proceedings of the $9^{\text {th }}$ International Congress on Deterioration and Conservation of Stone, June 19 - 24, 2000, Amsterdam, Elsevier, 313 - 318.

5. Cardell, C.; D. Benavente and J. R. Gordillo, 2008: Weathering of limestone building material by mixed sulfate solutions, characterization of stone micro-structure, reaction products and decay forms. Material characterization, $\mathrm{V}$. 59, P. $1371-1385$

6. Elaine, S.; G. M. McGee; and G. Victor, 1992: Gypsum accumulation on carbonate stone. Atmospheric Environment, V. 26B (2), P. $249-253$.

7. Fitzner, b. and K. Heinrichs, 2002: Damage diagnosis on stone monuments- weathering forms, damage categories and damage indices. Understanding and Managing stone decay, Prikryl and Viles "eds.", The Karolinum Press, 11 56.

8. Flatt, R. J., 2002: Salt damage in porous materials: how high supersaturations are generated. J. Crystal Growth, V. 242, P. $435-454$.

9. Flatt, R. J.; M. Steiger and G. W. Scheere, 2007: A commented translation of the paper by C. W. Correns and W. Steinborn on crystallization pressure. Environmental Geology, V. 52, P. 187 - 203.

10. Gauri, K. L.; C. H. George and C. V. Willard, 1986: Cleaning efflorescence from Masonry. ASTM, J.R. Clifton "ed", P. 3 - 13

11. Gauri, K. L., 1990: Decay and preservation of stone in modern environments. Environmental Geology and Water Science, V. 15 (1), P. 45 - 54.

12. Geological Society Engineering Group Working Party, 1977: The description of rock masses for engineering purposes. QJEG, V. 10, P. 355 - 388. 
13. Horiya, M. A., 2012: Quantified damage category of some Pharaonic archaeological sites at Bahariya Oasis, Western Desert, Egypt, and Examining their modes of restoration. MSc thesis, Fac. of Sci., Menoufiya Univ., Egype, Unpublished.

14. Kamh, G. M. E., 2007: Field and laboratory investigations of damage intensity of the Upper Cretaceous monumental sandstone of Dendara Temple, Upper Egypt, a Case study. International Journal for Restoration of Buildings and Monuments, V. 13 (5), P. 331 - 354.

15. Kamh, G. M. E. and R. Azzam, 2008: Field and laboratory investigations to examine the damage category of monumental sandstone in arid regions: Seti I Temple, Upper Egypt, a case study. Int. Journal for Restoration of Buildings and Monuments, V. 14 (3), P. $179-196$.

16. Kapranos, P. A.; M. H. A. Al-Helaly and V. N. Whittaker, 1981: Ultrasonic velocity measurements in 316 Austenitic Weldments. British Journal of Non-destructive Testing, V. 23 (6), P. $211-222$.

17. Montoto, M.; L. Callega; B. Perez and R. M. Esbert, 1981: Evaluation in situ of the state of deterioration of monumental Stones by non-destructive ultrasonic techniques. Mat. Res. Soc. Symp. Proc. 1981, V. 185, P. 273 284.

18. Mustoe, G. E., 1983: Cavernous weathering in the Capitol reef desert, UTAH. Earth Surface Processes and Landforms, V. 8, P. 517 - 526.

19. Robinson, D. A., 1974: A note on the expression of soil moisture content. J. Area, V. 6; P. 9 - 13.

20. Robinson, D. A. and R. B. G. Williams, 1994: Sandstone weathering and landforms in Britain and Europe. Rock Weathering and Landform Evolution, Robinson and Williams "eds", P. $371-389$.

21. Rudrich, J.; T. Bartelsen; R. Dohrmann and S. Siegesmund, 2011: Moisture expansion as a deterioration factor for sandstone used in buildings. Environmental Earth Sciences, V. 63, P. 1573 - 1586.

22. Said, R., 1990: The Geology of Egypt. Rotterda: Balkema, P. 734.

23. Salman, A. B.; F. M. Howari; M. M. El-Sankary; A. M. Wali and M. M. Saleh, 2010: Environmental impact and natural hazards on Kharga Oasis monumental sites, Western Desert of Egypt. Journal of African Earth Sciences, V. 58, P. $341-353$.

24. Shin, M. and P. Frank, 1993: Environmental monitoring at the Tomb of Nefertari. The Getty Conservation Institute, 4503 Glencoe Avenue, Marina del Rey, CA 90292- 6537 USA), ICOM Committee for conservation, P. 616 - 622.

25. Swe, Y.; and C. T. Oguchi, 2009: Complex relationship between salt type and rock properties in a durability experiment of multiple salt-rock treatments. Earth Surface Processes and Landforms, V. 34, P. $2096-2110$.

26. Vendrell, M. S.; M. Garcia-valles and S. Alarcon, 1996: Environmental impact on the Roman monuments of Tarragona, Spain. Environmental Geology, v. 27, P. 263 - 269.

27. Waltham, A. C., 1993: Crown hole development in the sandstone caves of Nottingham. QJEG, V. 26, P. 243 - 251.

28. Zehnder, K., 2007: Long-term monitoring of wall paintings affected by soluble salts. Environmental Geology, V. 52 , P. $353-367$.

29.

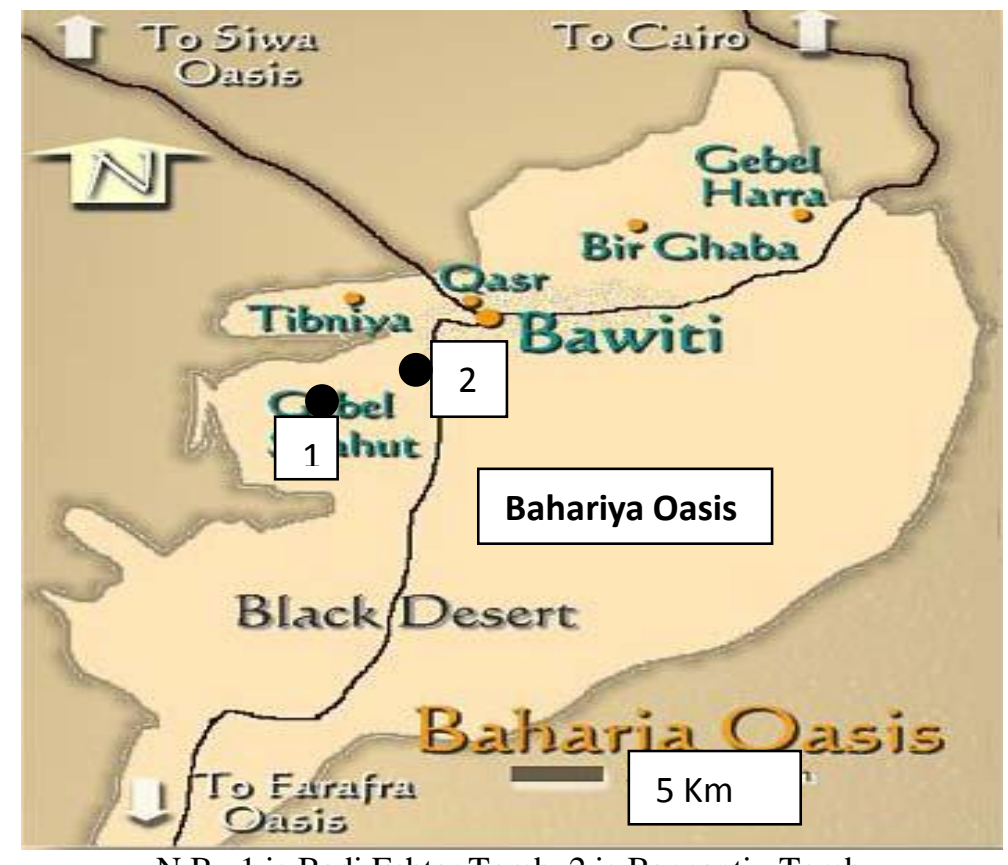

N.B. 1 is Badi Eshtar Tomb, 2 is Bannantiu Tomb

Figure 1: Map of Bahariya Oasis with location of the sites under investigation 


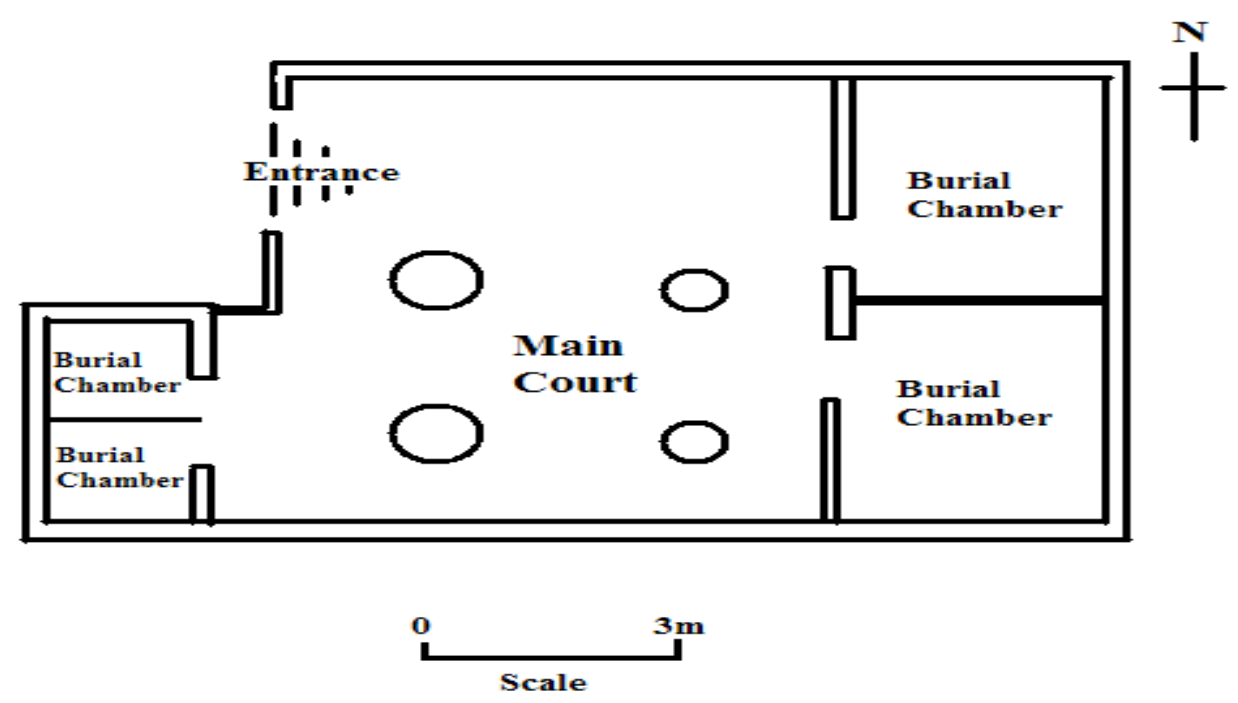

Figure 2: Sketch diagram of Bannantiu Tomb, Bahariya Oasis, Egypt.

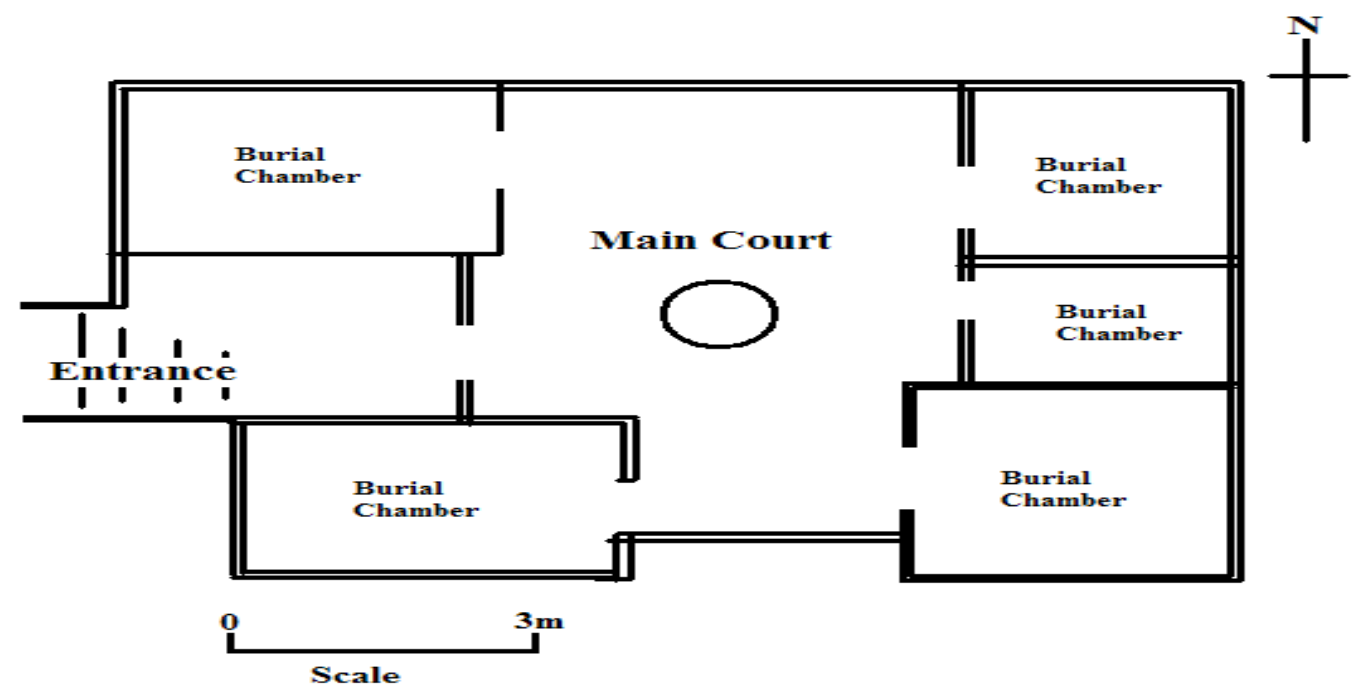

Figure 3: Sketch diagram of Badi Eshtar Tomb, Bahariya Oasis, Egypt

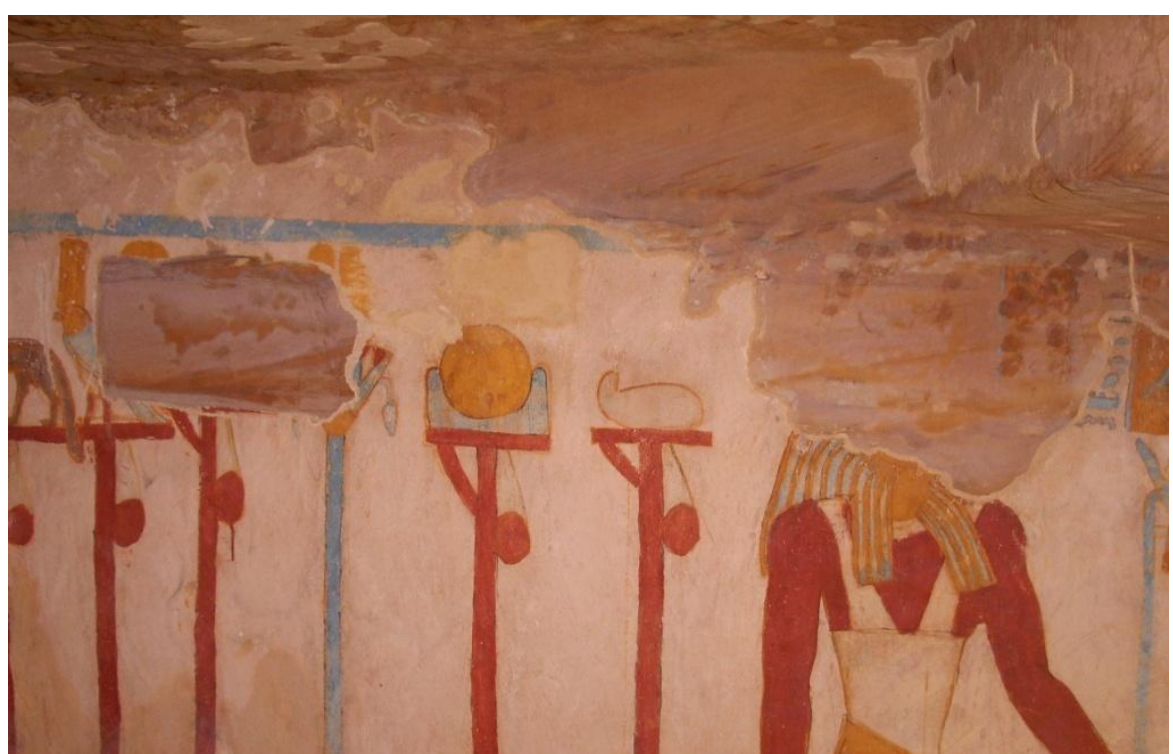

Figure 4: Obliteration of wall paints at dark brown ferruginous facies of the bedrock at Bannantiu Tomb, Bahariya Oasis, Egypt. 


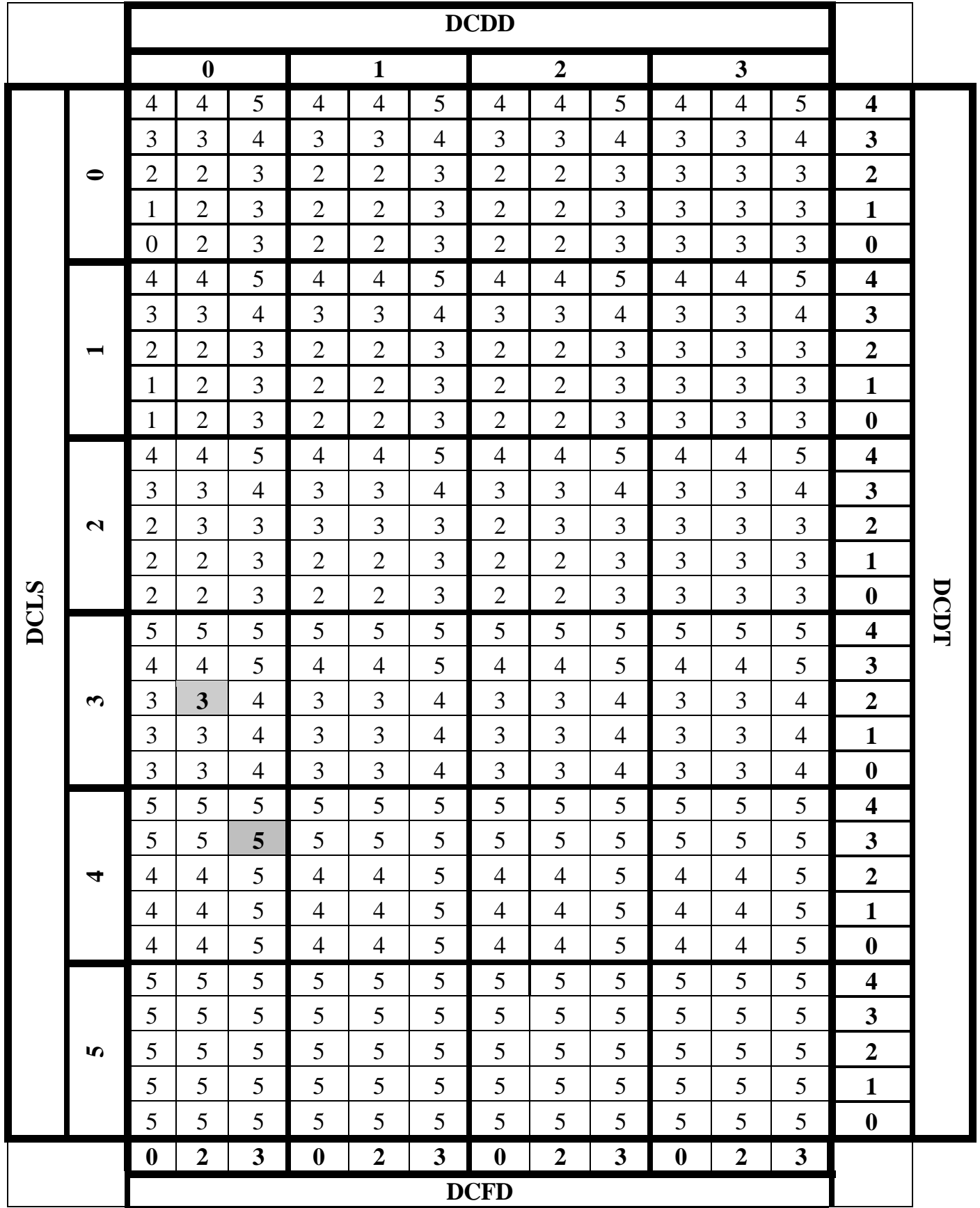

N.B. DCAW is Damage Category including All Weathering Forms

\begin{tabular}{|c|l|l|l|}
\hline 3 & Main Court, Light Brown facies & DCLS & $\begin{array}{l}\text { Is Damage category regarding Loss of Stone } \\
\text { material }\end{array}$ \\
\hline $\mathbf{5}$ & Main Court, Dark Brown facies & $\mathbf{D C D T}$ & $\begin{array}{l}\text { Is Damage Category regarding Discoloration / } \\
\text { Deposition }\end{array}$ \\
\hline & & $\mathbf{D C F D}$ & $\begin{array}{l}\text { Is Damage Category regarding Detachment } \\
\text { Fissures/Deformation }\end{array}$ \\
\hline
\end{tabular}

Figure 5: DCAW of Fitzner and Heinrichs "2002” for semi-quantification of damage category at the Main Court of Badi Eshtar Tomb, Bahariya Oasis. 


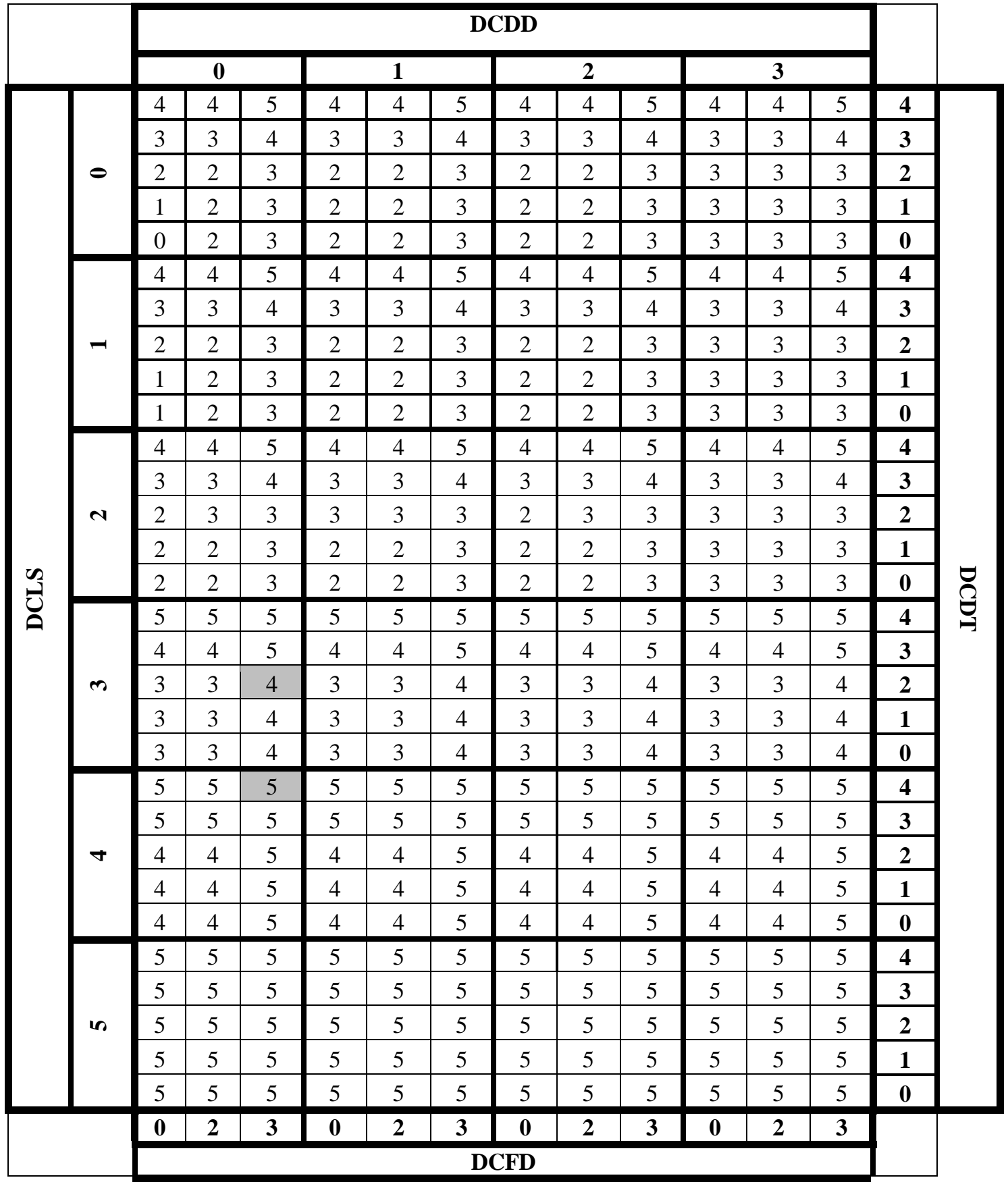

N.B. DCAW is Damage Category including All Weathering Forms

\begin{tabular}{|c|l|l|l|}
\hline $\mathbf{4}$ & Main Court, Light Brown facies & DCLS & $\begin{array}{l}\text { Is Damage category regarding Loss of Stone } \\
\text { material }\end{array}$ \\
\hline $\mathbf{5}$ & Main Court, Dark Brown facies & $\mathbf{D C D T}$ & $\begin{array}{l}\text { Is Damage Category regarding Discoloration / } \\
\text { Deposition }\end{array}$ \\
\hline & & $\mathbf{D C F D}$ & $\begin{array}{l}\text { Is Damage Category regarding Detachment } \\
\text { Fissures/Deformation }\end{array}$ \\
\hline
\end{tabular}

Figure 6: DCAW of Fitzner and Heinrichs "2002" for semi-quantification of damage category at the Main Court of Bannantiu Tomb, Bahariya Oasis. 


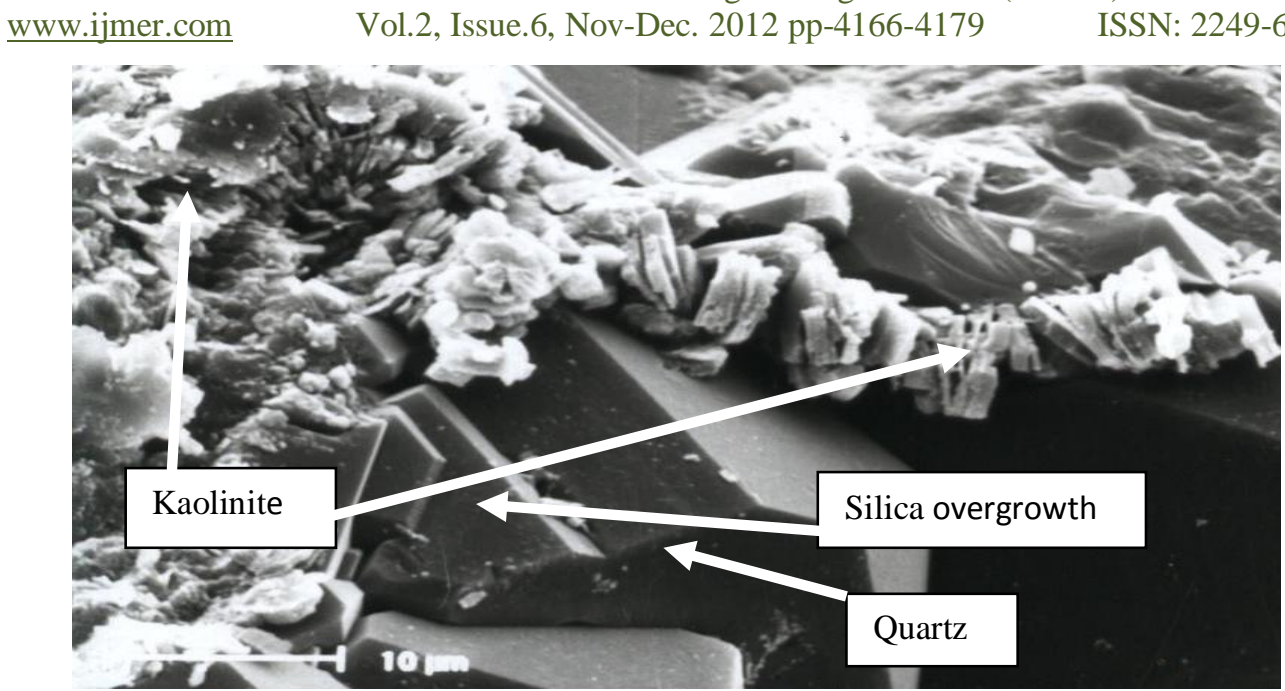

Figure 7: Representative Scanning electron photo-micrograph presenting components of rock sample collected at BadiEshtar and Bannantiu Tomivo, rirartz with silica overgrowth and kaolinite can be noted.

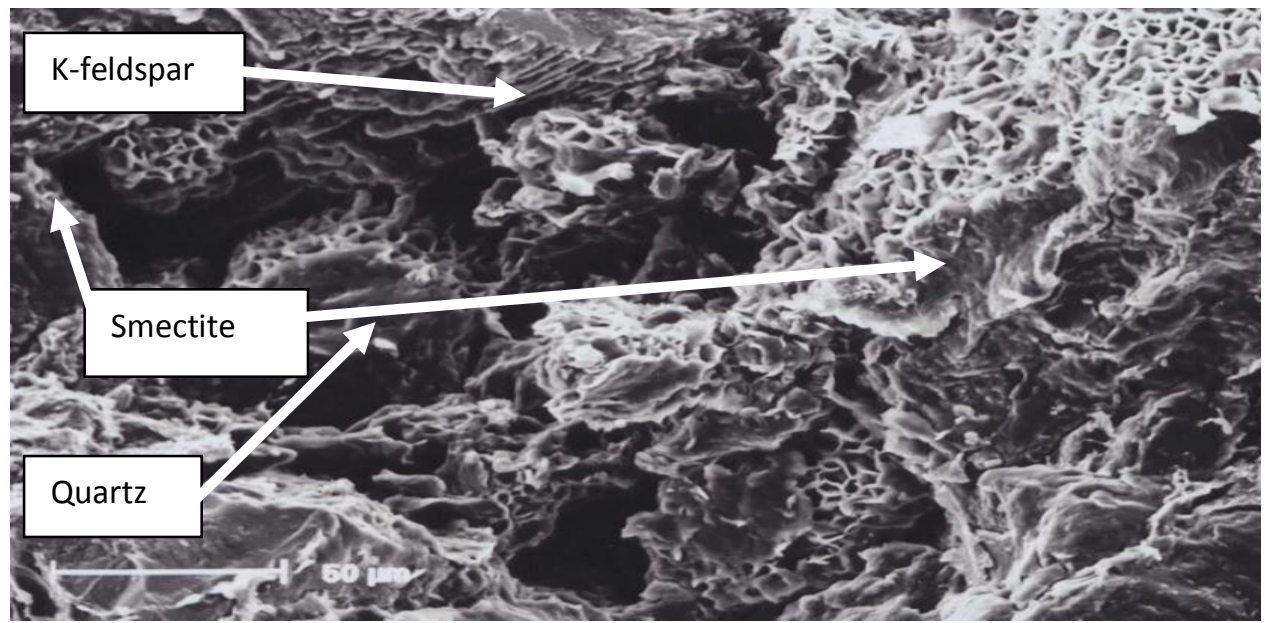

Figure 8: Representative Scanning electron photo-micrograph presenting Quartz, K- feldspar and Smectite for a rock sample collected at the bedrock of Badi-Eshtar and Bannantiu Tombs.

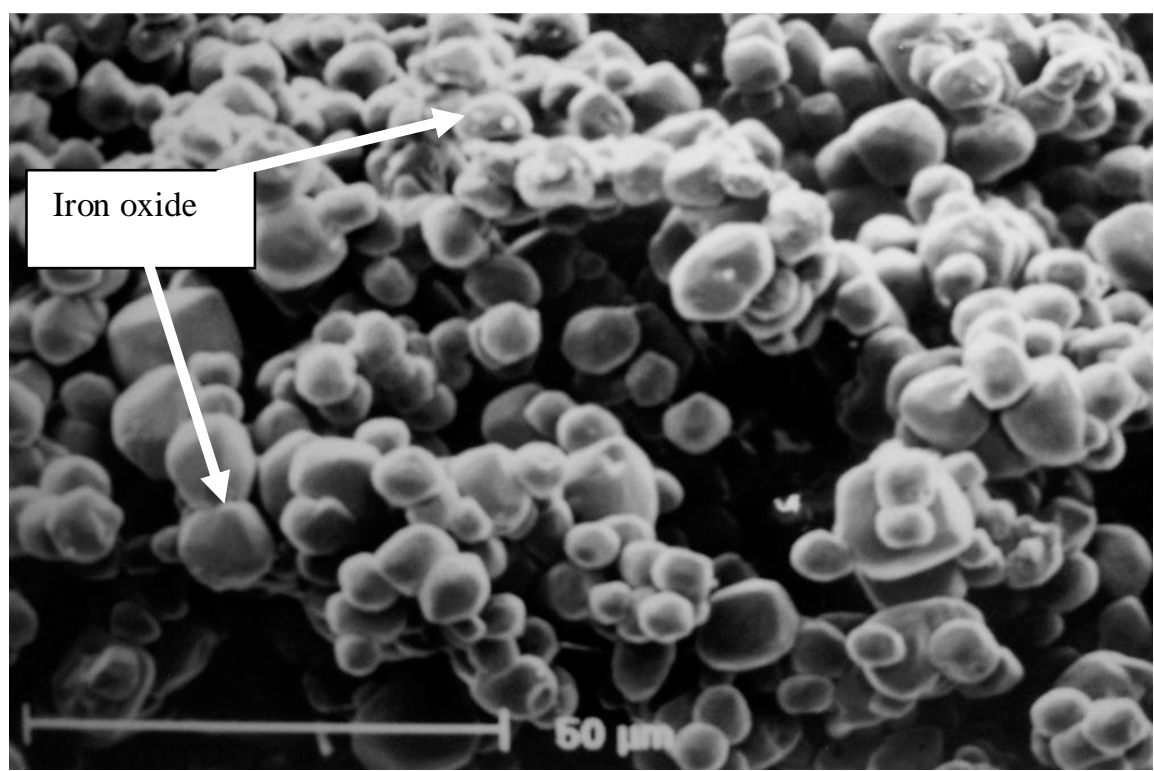

Figure 9: Scanning electron representative photo-micrograph presenting iron oxide balls coating quartz grains of the dark brown sandstone samples at the tombs under investigation. 


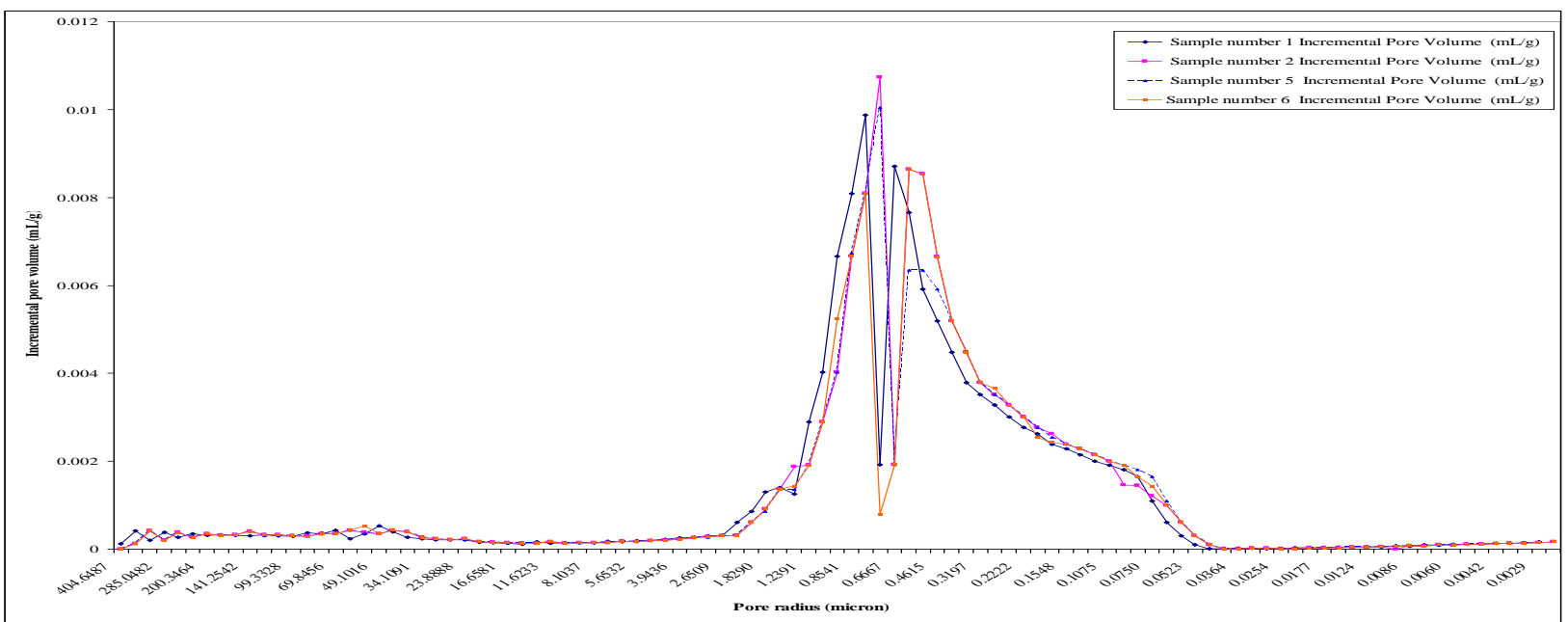

Figure 10: Graphical relationship between pore radius and Incremental pore volume for sandstone samples number 1,2,5 and 6 collected at dark brown facies of Bannantiu and Badi Eshtar Tombs, Bahariya Oasis, Egypt.

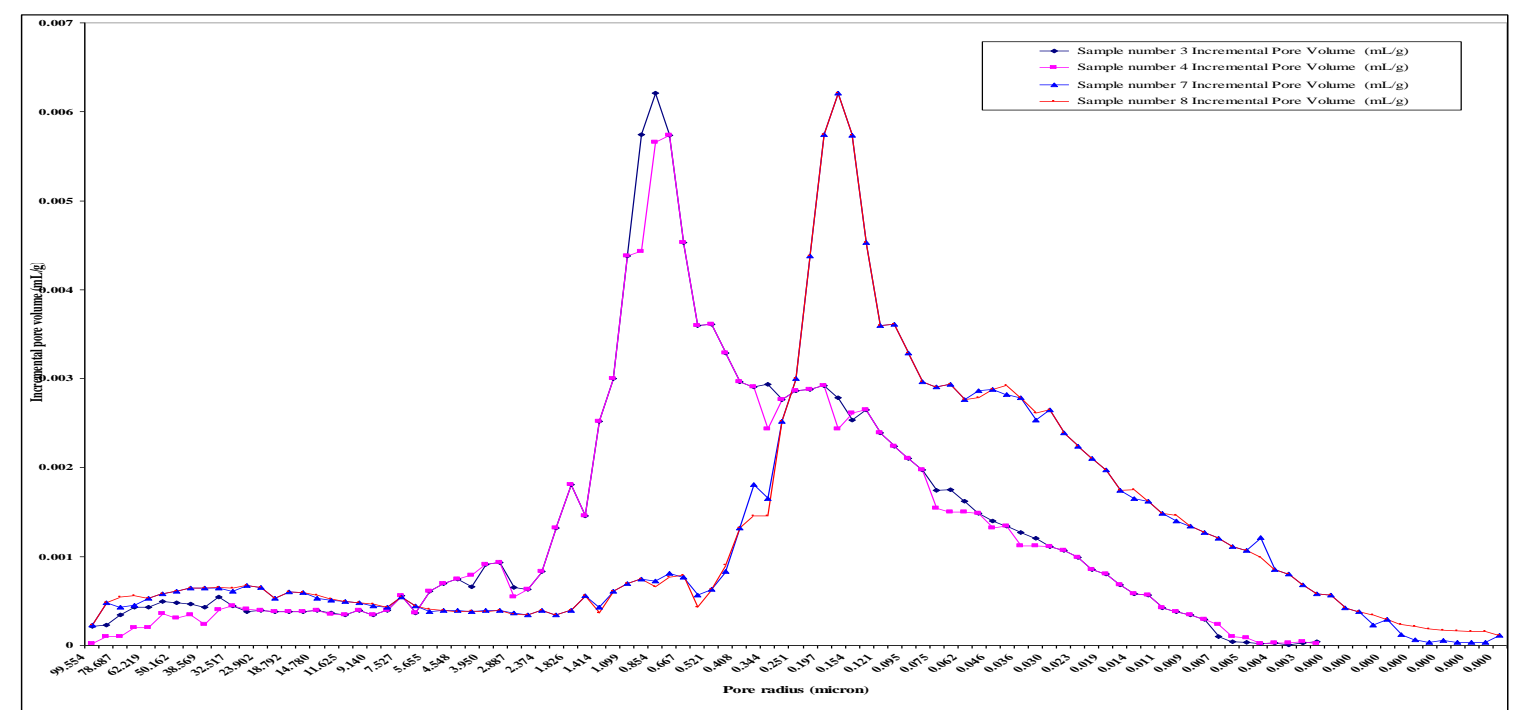

Figure 11: Graphical relationship between pore radius and Incremental pore volume for sandstone samples number 3,4,7 and 8 collected at Light brown facies of Bannantiu and Badi Eshtar Tombs, Bahariya Oasis, Egypt.

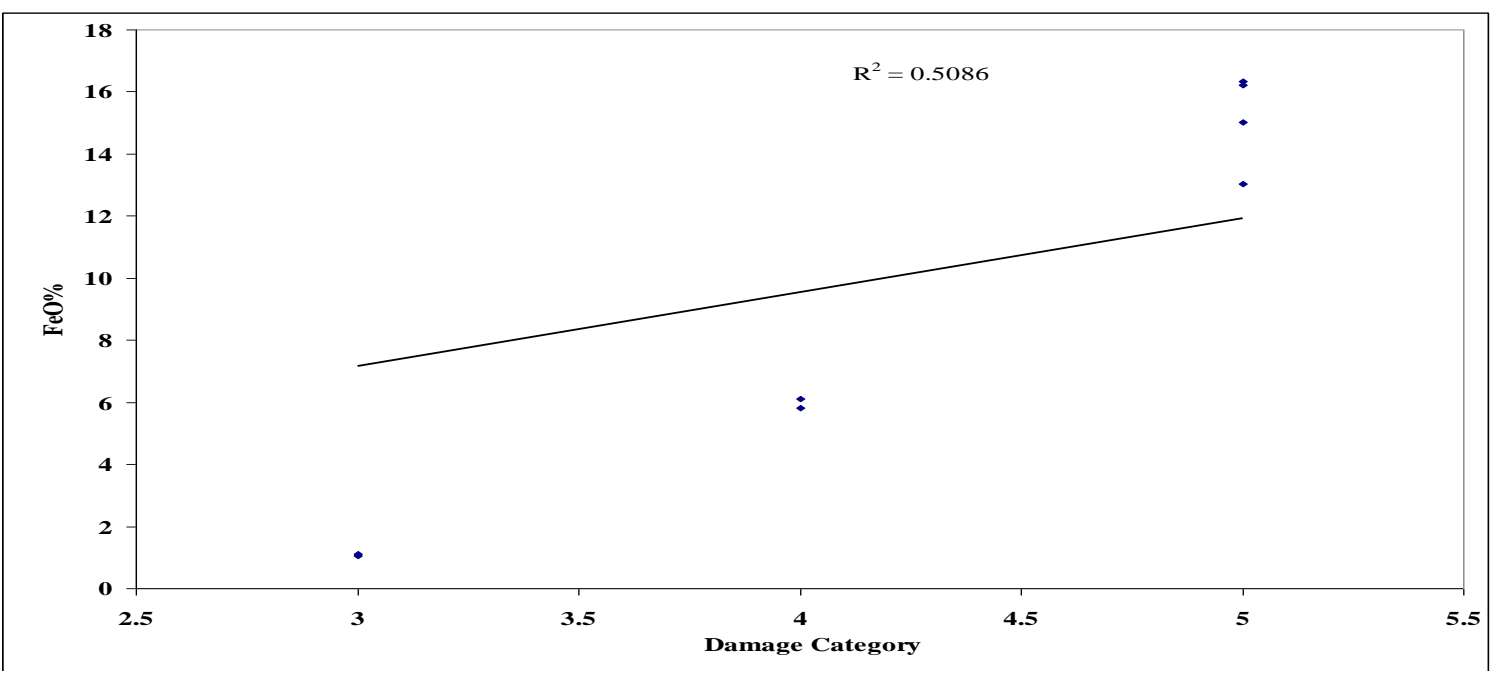

Figure 12: Binary relationship between Overall DC and rock's iron oxide content at the tombs under investigation. 